\title{
Pyuria and microbiology in acute bacterial focal nephritis: a systematic review
}

Simone Janett1,2, Gregorio P. Milani3,4, Pietro B. Faré ${ }^{1}$, Samuele Renzi ${ }^{2 *}$, Olivier Giannini ${ }^{5}$, Mario G. Bianchetti ${ }^{2,6}$, Sebastiano A. G. Lava7 ${ }^{1}$ Department of Internal Medicine, Ente Ospedaliero Cantonale, Locarno, Switzerland;

${ }^{2}$ Pediatric Institute of Southern Switzerland, Ospedale San Giovanni, Bellinzona, Switzerland;

3Pediatric Unit, Fondazione IRCCS $\mathrm{Ca}^{\prime}$ Granda Ospedale Maggiore Policlinico, Milan, Italy;

4Department of Clinical Sciences and Community Health, Università degli Studi di Milano, Milan, Italy;

${ }^{5}$ Department of Internal Medicine, Ente Ospedaliero Cantonale, Mendrisio, Switzerland;

${ }^{6}$ Università della Svizzera Italiana, Lugano, Switzerland;

${ }^{7}$ Cardiology Unit, Department of Pediatrics, Centre Hospitalier Universitaire Vaudois, Lausanne, Switzerland.

* Present appointment: Division of Haematology and Oncology, the Hospital for Sick Children, Toronto, Canada.

Corresponding author: Gregorio P Milani, Pediatric unit, Foundation 
IRCCS Ca' Granda, Ospedale Maggiore Policlinico, via della Commenda 9, 20122 Milan, Italy. Tel: 0039(0)255038727, Fax: 0039(0)255032918, email: milani.gregoriop@gmail.com 


\section{Abstract}

INTRODUCTION: presentation and imaging findings of acute focal bacterial nephritis, a localized renal infection not containing drainable pus, have been extensively addressed. The aim of this review was to assess the prevalence of cases without pyuria or bacteriuria and the spectrum of microorganisms underlying this condition. EVIDENCE ACQUISITION: we conducted a systematic review of the literature in the National Library of Medicine and Excerpta Medica databases. For the final analysis, we retained 54 reports published between 1981 and 2018 describing 251 patients affected by focal bacterial nephritis, who have been specifically investigated with respect to urinalysis and standard bacterial cultures. They were 177 (102 females and 75 males) subjects $\leq 20$ and 74 (57 females and 17 males) $>20$ years of age. EVIDENCE SYNTHESIS: Pyuria and bacteriuria were absent in 33 cases, while pyuria was not associated with bacteriuria in 5 further cases. The vast majority of culturepositive cases were caused by Enterobacteriaceae (slightly less than $80 \%$ ) and Pseudomonas species (approximately 10\%). Enterococcus species and Staphylococcus aureus were isolated in slightly more than $10 \%$ of the cases. ConcLusions: a large subset of patients affected by focal bacterial nephritis present without pyuria and significant bacteriuria. The initial management consists of broad- 
spectrum antimicrobials with high tissue penetration, active against Enterobacteriaceae, Pseudomonas species, Enterococcus species and Staphylococcus aureus.

Key words: Kidney diseases • microbiology • pyuria • urinalysis • lobar nephronia $\cdot$ abscess

\section{Abbreviations}

None 


\section{Introduction}

Acute urinary infections include both infections of the urinary tract and infections of the kidney [1, 2]. The latter spans continuously from pyelonephritis to frank abscess [1-3]. Among this suite of renal infections, acute focal bacterial nephritis, also known as lobar nephronia, is a localized area of renal infection not containing drainable pus, which typically involves one, or less frequently, more lobes [3]. In this rather uncommon condition with unknown prevalence, clinical presentation and imaging findings have been extensively addressed [4]

The initial assessment for subjects with suspected urinary infection includes urinalysis and culture [1, 2]. Pyuria and significant bacteriuria are usually necessary to make the diagnosis. Some patients affected by acute bacterial focal nephritis have negative urinalysis and culture. This fact results in delays in diagnosis and, consequently, management. Furthermore, there is so far limited information about the microorganisms causing this infection.

The aim of this review was to assess the prevalence of cases without pyuria or bacteriuria and the spectrum of microorganisms underlying this condition.

\section{Methods}




\section{Literature search strategy}

We recently conducted a search with no date limits of the Medical Subject Headings terms "focal bacterial nephritis" OR "acute focal nephritis" OR "acute lobar nephronia" OR "acute nephronia" in the National Library of Medicine and Excerpta Medica databases. The literature of each included article was also screened. The review was performed according to the Economic and Social Research Council guidance on the conduct of narrative synthesis and on the Preferred Reporting Items for Systematic Reviews and Meta-Analyses statement.

\section{Selection criteria}

We selected original articles reporting cases of acute focal bacterial nephritis, which specifically address urinalysis and microbiological findings. Reports published in Spanish, Portuguese, Italian, German, French, English and Dutch were eligible. For the final analysis, we included apparently immunocompetent subjects of both genders and a poorly defined, irregularly margined focal mass with hyper-, iso-, or hypoechogenicity or a generalized kidney enlargement on imaging [3, 4]. Pyuria and bacteriuria were not a prerequisite for inclusion. Cases with sterile pyuria possibly unrelated to the urinary tract were excluded.

\section{Data extraction}

Results of imaging tests completed in the original reports to support the diagnosis of acute focal bacterial nephritis were 
reviewed using recognized criteria [2-4]. From each reported case, the following information was sought, in addition to results of imaging studies, by means of a predefined database: 1) demographics; 2 ) urinalysis; 3) standard bacterial cultures; and 4) pre-existing renal conditions.

\section{Analysis}

The literature search and the data extraction were independently carried out by two of us (S.J. and S.R.). If the extracted data were incongruent, conflicts were resolved by reaching a consensus. Results are given either as median and interquartile range, or as frequency, as appropriate. The kappa-test was used to assess the agreement between investigators on the application of inclusion and exclusion criteria. The Fisher exact test was applied to compare frequency counts between groups. Statistical significance was assigned at $\mathrm{P}<0.05$.

\section{Results}

\section{Search Results}

The literature search process is summarized in Fig. 1. The chanceadjusted agreement between the two investigators was 0.89. For the final analysis, we retained 54 reports published between 1981 and 2018 [5-58]: twenty-four from Europe (Spain, N=13; United Kingdom, $\mathrm{N}=3$; Belgium, N=2; Germany, N=2; Croatia, N=1; Greece, N=1; Italy, 
$\mathrm{N}=1$; Portugal, $\mathrm{N}=1$ ), 17 from America (USA, N=13; Argentina, N=2; Chile, N=2), 12 from Asia (Japan, N=8; India, N=1; Taiwan, N=1; Thailand, N=1; Turkey, N=1) and 1 from Morocco. Thirty-six reports were published in English, 13 in Spanish, 2 in French, 2 in German and 1 in Portuguese.

\section{Findings}

The aforementioned reports described 251 patients (159 females and 92 males) affected by focal bacterial nephritis, who have been specifically investigated with respect to urinalysis and standard bacterial cultures. There were 177 ( 102 females and 75 males) subjects $\leq 20$ and 74 ( 57 females and 17 males) $>20$ years of age. Pyuria and bacteriuria were absent in 33 cases, while pyuria was not associated with bacteriuria in 5 further cases (table 1 ). A negative bacterial culture was more common $(P<0.02)$ in the group of patients $\leq 20$ years of age. Antimicrobial administration had preceded diagnostic urinary investigations in 14 of the 38 culture-negative cases, pointing out that 24 (10\%) out of the 237 cases without antimicrobial pretreatment had an unexplained negative urine culture.

A total of 213 (85\%) patients were culture-positive (regrettably, information about the identified germ was not available in 15 cases). The germs isolated in 198 patients are depicted in table 2 . The vast majority of cases were caused by Enterobacteriaceae (almost $80 \%$ ) and Pseudomonas species (approximately 10\%). Enterococcus 
species and Staphylococcus aureus were isolated in about $10 \%$ of cases. In 27 (14\%) cases, the germ was isolated both in blood and urine. No case presented with a positive blood culture and a negative urine culture.

Since information on pre-existing renal conditions was found in $<20$ of the 251 cases, these data were deliberately not analyzed.

\section{Discussion}

Urinary findings and microbiology of urinary infections are well established [1,2]. This analysis performed in acute focal bacterial nephritis suggests that $10 \%$ of the cases present without pyuria and significant bacteriuria. The study also points out that Enterobacteriaceae and Pseudomonas species are the predominant pathogens, followed by enterococci and staphylococci. The discussion will address the prevalence of cases without bacteriuria, the spectrum of microorganisms underlying this condition, and finally both the clinico-laboratory features and the management.

Since antimicrobial pretreatment of a urinary infection rapidly decreases the rate of culture-positivity $[1,2]$, this analysis points out that at least every tenth case of acute bacterial focal nephritis is culture-negative (more frequently children than adults). On the contrary, urine cultures are normally positive (and associated with a positive test for leukocytes and nitrites) in untreated children and adults with a febrile urinary tract infection 
$[1,2]$. In this severe infection, the rather common occurrence of both leucocyte- and culture-negativity suggests that this entity, like renal abscess, sometimes does not communicate with the urinary collecting system [3, 4]. Furthermore, we assume that, like renal and perirenal abscess, focal bacterial nephritis occurs as a complication of a urinary tract infection or secondary to an hematogenous spread $[3,4]$.

Enterobacteriaceae, most frequently Escherichia coli, are the predominant pathogens both in uncomplicated community-acquired urinary tract infection and focal nephritis $[1,2,59,60]$. By contrast, Pseudomonas, Enterococci and Staphylococci appear to be more common in focal nephritis as compared with community-acquired urinary tract infection. Pseudomonas is usually identified in cases with history of urinary tract infections, anatomic abnormalities or use of antimicrobials [61]. Enterococci are relevant uropathogens in subjects with an anatomic abnormality or in hospitalized patients [62]. Finally, Pseudomonas, Enterococci and Staphylococci are recognized pathogens in catheter-associated urinary tract infection [61-63]. Regrettably, the results of this study do not allow to confirm (or infirm) whether focal bacterial nephritis caused by Pseudomonas, Enterococci and Staphylococci predominantly occurs in subjects with anatomic abnormalities or use of antimicrobials. In patients with focal nephritis the diagnosis is often delayed, the duration of hospital stay prolonged and the risk of renal scar formation high, which emphasizes the importance of a high level of 
suspicion.

This diagnosis should be considered in patients with or without altered urinalysis presented with prolonged fever, particularly if associated with flank pain and elevated inflammatory markers. In addition, the diagnosis should be suspected in pyelonephritis patients slow at responding to an appropriate antimicrobial therapy . Identification of focal bacterial nephritis on imaging confirms the suspicion. Echography carried out by an experienced examiner aware of the clinical suspicion using modern equipment is reliable for diagnosis. In many cases, however, computed tomography with contrast enhancement is used [4]. There is so far limited experience with magnetic resonance imaging with this condition.

There is no place for primary surgery in focal bacterial nephritis [3]. The mainstay of initial management consists of parenteral highdose broad-spectrum antimicrobials with high tissue penetration, active against Enterobacteriaceae, Pseudomonas species, Enterococcus species and Staphylococcus aureus. In addition to the predicted infecting organisms, the choice is based on a combination of patient factors and local microbial susceptibility patterns. Limited but plausible data suggest a total of three weeks of initial intravenous and subsequent oral antimicrobial therapy tailored to the cultured organism's susceptibility [64]. 


\section{References}

1. Foxman B (2014) Urinary tract infection syndromes: occurrence, recurrence, bacteriology, risk factors, and disease burden. Infect Dis Clin North Am 28:1-13. https://doi.org/10.1016/j.idc. 2013.09 .003 .

2. Balighian E, Burke M (2018) Urinary tract infections in children. Pediatr Rev 39:3-12. https://doi.org/10.1542/pir.2017-0007.

3. Dembry LM (2002) Renal and perirenal abscesses. Curr Treat Options Infect Dis 4:21-30.

4. Kawashima A, LeRoy AJ (2003) Radiologic evaluation of patients with renal infections. Infect Dis Clin North Am 17:433-456. https:// doi.org/10.1016/S0891-5520(03)00007-2.

5. McDonough WD, Sandler CM, Benson GS (1981) Acute focal bacterial nephritis: focal pyelonephritis that may simulate renal abscess. J Urol 126:670-673.

6. Siegel MJ, Glasier CM (1981) Acute focal bacterial nephritis in children: significance of ureteral reflux. AJR Am J Roentgenol $137: 257-260$.

7. Lawson GR, White FE, Alexander FW (1985) Acute focal bacterial nephritis. Arch Dis Child 60:475-477.

8. Zaontz MR, Pahira JJ, Wolfman M, Gargurevich AJ, Zeman RK (1985) Acute focal bacterial nephritis: a systematic approach to diagnosis and treatment. J Urol 133:752-757.

9. Dochy P, Lemmens L, Berneman Z, Van Herreweghe W (1986) Acute focal bacterial nephritis (acute lobar nephronia). J Belge Radiol $69: 431-434$.

10. Wegenke JD, Malek GH, Alter AJ, Olson JG (1986) Acute lobular nephronia. J Urol 135:343-345.

11. Frosch M, Ganser G, Schmidt H, Bulla M (1987) Die akute fokale bakterielle Nephritis (AFBN) im Kindesalter. Monatsschr Kinderheilkd $135: 842-846$.

12. Cox SM, Cunningham FG (1988) Acute focal pyelonephritis (lobar nephronia) complicating pregnancy. Obstet Gynecol 71:510-511.

13. Derouet H, Braedel HU, Mast GJ, Ziegler M (1988)

Computertomographie bei akuten bakteriellen Nierenentzündungen. Rofo $148: 54-57$.

14. Kline MW, Kaplan SL, Baker CJ (1988) Acute focal bacterial nephritis: diverse clinical presentations in pediatric patients. Pediatr Infect Dis J 7:346-349.

15. Edelstein H, MCCabe RE (1989) Perinephric abscess in pediatric patients: report of six cases and review of the literature. Pediatr Infect Dis J 8:167-170.

16. Gracia Chapulle A, Páramo Jaudenes C, Vita Saiz MJ, Otero

Martínez B, Fernández Menéndez JM, Matesanz Pérez JL (1989) Nefronía 
lobar aguda (pielonefritis bacteriana focal). A propósito de tres casos den edad pediátrica. An Esp Pediatr 30:377-379.

17. Cuenca R, Simeón CP, Torrents C, Fonollosa V (1990) Nefritis acute bacteriana focal. A propósito de un caso. Med Clin (Barc) $95: 234$.

18. Rathore MH, Barton LL, Luisiri A (1991) Acute lobar nephronia: a review. Pediatrics 87:728-734.

19. Harris EE, Sweat M, Katsanis WA, Aronoff GR (1992) Case report: acute focal bacterial pyelonephritis (lobar nephronia) presentation as a palpable abdominal mass. Am J Med Sci 304:303-305. 20. Boam WD, Miser WF (1995) Acute focal bacterial pyelonephritis. Am Fam Physician 52:919-924.

21. Wood GN, Kalra PA, Mamtora H, Waldek S, Donoghue DJ (1995) A febrile patient with a renal space-occupying lesion evolving into renal abscess: acute focal bacterial nephritis. Nephrol Dial Transplant 10:1248-1250. https://doi.org/10.1093/ndt/10.7.1248.

22. Kumar PD, Brown LA (2000) Focal bacterial nephritis (lobar nephronia) presenting as renal mass. Am J Med Sci 320:209-211. https : //doi.org/10.1016/S0002-9629(15)40820-1.

23. Rodrigo Guanter V, Serrano Durbá A, Domínguez Hinajeros C, García Ibarra F (2000) Nefronía lobar aguda. Presentación de un caso en la edad pediátrica. Arch Esp Urol 53:249-251.

24. Frieyro Seguí MI, Martín Aguado MJ, Canals Baeza A, Molla Nicova J, Camps Herrero J (2001) Segarra Aznar F. Nefronía lobar aguda. Aportación de tres nuevos casos. An Esp Pediatr 55:269-272. http:// dx.doi.org/10.1016/S1695-4033(01)77678-3.

25. García-Penit FJ, García De Vicuña FM, Collado Serra A, Gascón LG, Montilleó M (2001) Tumor renal espúreo: nefronía lobar aguda (NLA). Arch Esp Urol 54:66-69.

26. Ameur A, Lezrek M, Boumdin H, Beddouch A (2002) Néphrite bactérienne focale. Difficultés diagnostiques. Progr Urol $12: 479-481$.

27. Montejo M, Santiago MJ, Aguirrebengoa K, Garcia B, Goicoetxea J, Martin A (2002) Acute focal bacterial nephritis: report of four cases. Nephron 92:213-215. https://doi.org/10.1159/000064465.

28. Rodríguez Alonso A., González Blanco A, Bonelli Martín C, Cachay Ayala ME, Suárez Dono IM, Lorenzo Franco J, Cuerpo-Pérez MA, NietoGarcía J (2002) Nefritis bacteriana aguda difusa en riňón en herradura. Actas Urol Esp 26:806-810.

29. Estevinho N, Ferreira AM, Pinto A, Costa MV, Sodré Borges BP (2003) Nefronia Lobar aguda em lactente: caso clínico. Acta Pediatr Port 34:287-289.

30. Makanda TA, Bricteux G, de Leval J, Boverie J (2004) La néphrite focale bactérienne aiguë. Rev Med Liège 59:16-18. 
31. Merino-Palacios C, Belda-Mira A, Aragó-Galindo M, Serra-Sanchís B (2005) Síndrome febril prolongado sin focalidad. Enferm Infecc Microbiol Clin 23:627-628.

32. Shimizu M, Katayama K, Kato E, Miyayama S, Sugata T, Ohta K (2005) Evolution of acute focal bacterial nephritis into a renal abscess. Pediatr Nephrol 20:93-95. https://doi.org/10.1007/ s00467-004-1646-2.

33. Wan KS, Chen CA (2006) Acute focal bacterial nephritis in an 8year-old. Nephrology (Carlton) 11:238-239. https://doi.org/10.1111/ j.1440-1797.2006.00574.x.

34. Granados Molina A, Espino Hernández M, Gancedo Baranda A, Albillos Merino JC, Álvarez-Cortinas JF, Molina Amores C (2007) Nefronía focal aguda bacteriana: diagnóstico, tratamiento y evolución. An Pediatr (Barc) 66:84-86. https://doi.org/ $10.1157 / 13097366$.

35. Arrabal-Polo MA, Arrabal-Martín M, Valle-Díaz de la Guardia F, Zuluaga-Gómez A (2009) Acute lobar nephronía. Rev Med Chil $137: 1401-1402$.

36. Cano FS, Strodthoof FR, Muñoz O (2010) Nefritis aguda focal. Caso clínico. Rev Chil Pediatr 81:247-252.

37. Vijayakumar M, Prahlad N, Nandhini G, Prasad N, Muralinath S (2010) Child with acute lobar nephronia. Indian J Nephrol 20:162165 .

38. Custović $Z$, Šoša S (2011) Focal bacterial nephritis masquerading as renal cell carcinoma: case report. Acta Clin Croat 50:113-114. 39. Dellavedova T, Ponzano R, Racca L, Tavip L, Nóbile R, Arselán S, Minuzzi F (2011) Pielonefritis bacteriana focal aguda. Comunicación de un caso. Rev Arg Urol 76:36-38.

40. Rianthavorn P (2011) Progression and resolution of acute focal bacterial nephritis. Iran J Kidney Dis 5:271-274.

41. Doyle Sánchez M, Vidal Company A, Ramírez Martínez N (2012) Nefronía lobar aguda: a propósito de tres casos. Acta Pediatr Esp $70: 35-37$.

42. Rafi J, Smith RB (2012) Acute lobar nephronia in pregnancy: a rarely reported entity in obstetric renal medicine. Arch Gynecol Obstet 286:797-798. https://doi.org/10.1007/s00404-012-2309-3.

43. Alaygut D, Bayram M, Soylu A, Türkmen M, Kavukçu S (2013) Acute focal bacterial nephritis developed in a healthy child. Turk $\mathrm{J}$ Pediatr 55:226-228.

44. Falcón MV, Finn BC, Korin L, Emery NC, Young P (2013) Nefritis bacteriana focal aguda por Staphylococcus aureus meticilino resistente. Medicina (B Aires) 73:288-290.

45. Saito $K$, Fuchigami $T$, Hasegawa $N$, Kawamura $Y$, Hashimoto $K$, Fujita Y, Inamo Y, Takahashi S (2013) Clinical features of acute 
focal bacterial nephritis in children. Int J Clin Pediatr 2:68-73. http://dx.doi.org/10.4021/ijcp115w.

46. Adams N, Johnson MD, Storm DW, Maves RC (2014) Acute focal bacterial nephritis due to methicillin-resistant Staphylococcus aureus in an immunocompetent adult. Infection 42:433-436. https:// doi.org/10.1007/s15010-013-0553-5.

47. Conley SP, Frumkin K (2014) Acute lobar nephronia: a case report and literature review. J Emerg Med 46:624-626. https://doi.org/ $10.1016 / j . j e m e r m e d .2013 .08 .097$.

48. Iga R, Uchino $\mathrm{H}$, Kanazawa K, Usui S, Miyagi M, Kumashiro N, Hirose $T$ (2014) Acute focal bacterial nephritis in an occupational allergy. Lancet Infect Dis 14:656. https://doi.org/10.1016/ S1473-3099(14)70738-8.

49. Kometani H, Kawatani M, Ohta G, Okazaki S, Ogura K, Yasutomi M, Tanizawa A, Ohshima Y (2014) Marked elevation of interleukin-6 in mild encephalopathy with a reversible splenial lesion (MERS) associated with acute focal bacterial nephritis caused by Enterococcus faecalis. Brain Dev 36:551-553. https://doi.org/ $10.1016 / j$.braindev.2013.07.012.

50. Maeshiro T, Hokama A, Fujita J (2014) Acute focal bacterial nephritis. BMJ Case Rep 2014 pii: bcr2014205199. https://doi.org/ $10.1136 /$ bcr-2014-205199.

51.Penela Vélez De Guevara MT, Alarcón Alacio MT, García-Vao Bel C, Rivero Martín MJ (2014) Nefritis focal aguda: nuestra experiencia. Bol Pediatr 54:156-159.

52. Sekine H, Kawasaki Y, Ohara S, Suyama K, Hosoya M (2014) Focal bacterial nephritis without pyuria in a boy presenting with high urinary $\beta 2-$ MG and NAG levels. Fukushima J Med Sci 60:91-94. https:// doi.org/10.5387/fms.2014-3.

53. Piñera C, Loyola F, Hernández P (2015) Nefronia en pediatría: dentro del espectro de las infecciones urinarias. Serie clínica y revisión de la literature. Rev Chilena Infectol 32:564-568. https:// doi.org/10.4067/s0716-10182015000600011.

54. Vergara-Espitia AV, Gallo-Urina K, Landinez-Millán G, CamachoMoreno G, Lozano-Triana CJ (2015) Nefronía lobar aguda en un niño: reporte de caso. Rev Fac Med Univ Nac Colomb 63:321-324. https:// doi.org/10.15446/revfacmed.v63n2.47501.

55. Bibalo C, Apicella A, Guastalla V, Marzuillo P, Zennaro F, Tringali C, Taddio A, Germani C, Barbi E (2016) Acute lobar nephritis in children: Not so easy to recognize and manage. World $\mathrm{J}$ Clin Pediatr 5:136-142. https://doi.org/10.5409/wjcp.v5.i1.136.

56. Kasuga Y, Fuchigami T, Fukuda A, Takahashi S, Murai T, Yonezawa R, Miyashita M, Kohira R, Fujita Y, Takahashi S (2017) Acute focal bacterial nephritis associated with central nervous system manifestations: A report of 2 cases and review of the literature. 
Pediatr Emerg Care 3:418-421. https://doi.org/10.1097/PEC. 0000000000000739 .

57. Sieger N, Kyriazis I, Schaudinn A, Kallidonis P, Dietel A, Ganzer R, Liatsikos EN, Stolzenburg JU (2017) Acute focal bacterial nephritis can lead to unnecessary invasive procedures: A report of three cases. Urol Int 99:245-248. https://doi.org/10.1159/000441955. 58. Yamaguchi $H$, Nagase $H$, Ito $Y$, Matsunoshita $N$, Mizutani M, Matsushige T, Ishida Y, Toyoshima D, Kasai M, Kurosawa H, Maruyama A, Iijima K (2018) Acute focal bacterial nephritis characterized by acute encephalopathy with biphasic seizures and late reduced diffusion. J Infect Chemother 24:932-935. https://doi.org/10.1016/ j.jiac.2018.04.007.

59. Ronald A (2003) The etiology of urinary tract infection: traditional and emerging pathogens. Dis Mon 49:71-82. https:// doi.org/10.1067/mda.2003.8.

60. Levine MM (1985) Escherichia coli infections. N Engl J Med $313: 445-447$.

61. Mittal R, Aggarwal S, Sharma S, Chhibber S, Harjai K (2009) Urinary tract infections caused by Pseudomonas aeruginosa: a minireview. J Infect Public Health 2:101-111. https://doi.org/ $10.1016 / j \cdot j i p h .2009 .08 .003$.

62. Fisher K, Phillips C (2009) The ecology, epidemiology and virulence of Enterococcus. Microbiology 155:1749-1757. https:// doi.org/10.1099/mic.0.026385-0.

63. Ondusko DS, Nolt D (2018) Staphylococcus aureus. Pediatr Rev 39:287-298. https://doi.org/10.1542/pir.2017-0224.

64. Cheng $\mathrm{CH}$, Tsau YK, Lin TY (2006) Effective duration of antimicrobial therapy for the treatment of acute lobar nephronia. Pediatrics 117:e84-e89. https://doi.org/10.1542/peds.2005-0917.

\section{Notes}

Authors contribution: SJ, GPM and MGB conceptualized and designed the study, and drafted the article. SJ, PBF, SR and SAGL performed the literature search, extracted and analyzed the data, and critically revised the manuscript. OG gave a significant contribution in the revision of the article. All authors approved the final version of the manuscript as submitted. The authors would like to thank Alice Leblanc for careful revision of the English text.

\section{Compliance with ethical standards}

Ethics approval 
The design of this systematic review of the literature was approved by the ethical committee of the hospital.

\section{Conflict of interest}

The authors declare that they have no conflict of interest.

Statement of financial support

Dr. Gregorio P. Milani is the current recipient of research grants from the Fondazione G. \& D. de Marchi ONLUS.

\section{Figure - Legend}

\section{Figure 1}

Focal bacterial nephritis. Flowchart of the literature search process. 
Table 1. Standard urine cultures in patients affected by focal bacterial nephritis.

$\begin{array}{lll}\text { All } & \leq 20 & >20\end{array}$

Culture-negative, $\mathrm{N}$

Absent pyuria

With antimicrobial

pretreatment
38

33

14

13

34

4 *

*

1

$* P<0.02$ 
Table 2. Microorganisms isolated in 198 patients affected by acute bacterial focal nephritis. In 27 of the cases the germ was isolated both in blood and urine.

$\begin{array}{cc}\text { Urine } & \text { Blood } \\ (\mathrm{N}=198) & (\mathrm{N}=27)\end{array}$

Microorganism

$\mathbf{N} \quad \mathbf{N} \quad \%$

Enterobateriacae

$\begin{array}{lcccc}\text { Escherichia coli } & 130 & 66 & 19 & 70 \\ \text { Klebsiella species } & 15 & 7.6 & 0 & 0.0 \\ \text { Proteus species } & 7 & 3.5 & 0 & 0.0 \\ \text { Enterobacter species } & 2 & 1.0 & 1 & 3.7 \\ \text { Serratia species } & 1 & 0.5 & 1 & 3.7 \\ \text { Pseudomonas species } & 19 & 9.6 & 2 & 7.4 \\ \text { Enterococcus species } & 15 & 7.6 & 1 & 3.7 \\ \text { Staphylococcus aureus } & 9 & 4.5 & 3 & 11\end{array}$

